\title{
VERTICAL-FARMING IRRIGATION SYSTEM APPROPRIATE FOR LETTUCE AND CELERY CROPS
}

\author{
*Bedair, O. M.
}

\section{ABSTRACT}

The current experiment was carried out in greenhouse in the Central Laboratory of Agricultural Climate, Agricultural Research Center (ARC), Dokki, Giza, Egypt, to develop proper system for a Vertical Farming Irrigation System" VFS" for lettuce and celery crops, to get the best vegetative growth uniformity along vertical axis of planting column (tube), maximum water use efficiency (WUE) with minimum energy consumption, and maximum fresh yield per square meter floor. The effects of plant type, nozzle type, vertical-pipe nozzle position, and number of nozzles per vertical farming tube at operating pressure range of 150 to $300 \mathrm{kPa}$, on growth uniformity, fresh yield $\left(\mathrm{kg} / \mathrm{m}^{2}\right)$. Energy consumptive use and WUE were considered. The initial and operating cost, in addition to net profit of "VFS" are also discussed.

The main results are summarized as follows:

- The longest vegtative growth heights of lettuce and celery, recorded by using four nozzles along the vertical tube was 24 and $46 \mathrm{~cm}$ at bottom layer of the planted column of the vertical farming tube(VFT), with increased percent ratios of 37.5 and $52.3 \%$ compared with using one mini sprinkler nozzle for the two crops resp..

- The highest values of WUE under different number of nozzles and positions was 11.2, 8.8, and $8 \mathrm{~kg} / \mathrm{m}^{3}$ for lettuce crop, and 12.8, 12.4, $9.75 \mathrm{~kg} / \mathrm{m}^{3}$ for celery crop by using four, two, and one nozzle along the "VFT" axis, with increasing ratios of 21.5, $28.6 \%$ for lettuce crop, and 3, 23.8\% for celery crop, compared with micro and fogger nozzles resp..

- The maximum energy requirements of lettuce and celery crops were 111.1, $97.2 \mathrm{kj} / \mathrm{kg} / \mathrm{y}$ for lettuce and celery crops, by using four nozzles (75 $\mu m-D S$ ) along the "VFT" for all tested nozzle types.

- The best uniformity of vegetative growth was $96 \%$ by using four mini sprinkler nozzles along the "VFT" axis.

*Assist. Prof., Ag. Eng. Dep., Fac. Ag., Ain Shams U., Cairo, Egypt. 
- The maximum productivities of lettuce and celery fresh yield were recorded as $14,11,10 \mathrm{~kg} / \mathrm{m}^{2}$ for lettuce crop, and $16,12.5,11.5 \mathrm{~kg} / \mathrm{m}^{2}$ for celery crop, for mini sprinkler, micro sprinkler and fogger nozzles resp.,

- The maximum consumptive use of energy was $4.32 \mathrm{~kW} . \mathrm{h} / \mathrm{y}$, when using mini sprinkler nozzle, increased by $81 \%$ compared with fogger nozzle. Meanwhile the minimum consumptive use of energy was $0.6 \mathrm{~kW} . \mathrm{h} / \mathrm{y}$, when using fogger sprinkler nozzle.

- The maximum net profit was 1047, 1527LE/y/column for lettuce and celery crops, by using mini sprinkler $(75 \mu \mathrm{m}$-DS) with an increase of $42.7,41.1 \%$ for lettuce and celery crops, compared with using fogger nozzle $(45 \mu \mathrm{m}-\mathrm{DS})$.

Keywords: Aeroponics, Hydroponics, Vertical-Farming system "VFS", Lettuce, Celery.

\section{1- INTRODUCTION}

Egypt is confronting incredible difficulties with respect to expected emergencies. Quick increase of population joined with the limited share of the Nile water (55.5 billion cubic meters per year).

Farming uses around $85 \%$ of the yearly water asset. More than $70 \%$ of the expanded reclamation relies upon low land-use efficiency.

The global population is expected to reach 9 billion by 2050. A significant proportion of land will be urban, requiring a $70 \%$ increase in agricultural productivity (Corvalan et al. 2005; Tilman et al. 2011). Continued rural to urban migration is predicted to drive the expansion of urban landscapes and accelerate the loss of cultivated land surrounding towns and cities (Pandey and seto 2015). Coupled with land degradation and loss of soil fertility, due to land-use intensification and climate change, agricultural land is increasingly becoming scare (Foley et al. 2011; Lambin et al. 2013). Vertical farming has been proposed as an engineering solution to increase productivity per area by extending plant cultivation into the vertical dimension, thus enhancing land use efficiency for crop production (Eigenbrod and Gruda 2014). The optimum temperature and humidity levels in green house were $24^{\circ} \mathrm{c}, 72 \%$ and light 
intensity about $72 \mathrm{~W} / \mathrm{m}^{2}$, and $\mathrm{pH}$ ranged from 7.4 to 8.2 for lettuce crop (C. sonneveld and W.Voogt, 1999).

Aeroponics is the process of growing plants in an air or mist environment without the use of soil or an aggregate media.

Researchers have described aeroponics as a "valuable, simple, and rapid method for preliminary screening of genotypes for resistance to specific seedling blight or root.

There is a major hazard by utilizing aeroponics as a part of business because of specialized issues: there is no water support and no developing medium to retain dampness. On the cutoff chance of fog, the plant will dry out rapidly (Savvas and Passam 2002, Raviv and Lieth 2008).

WUE in aeroponics is based on the dry-plant weight produced by a unit volume of water (Schwab et al., 1981).

Aeroponics cropping systems are commonly today implemented in different types of horizontal cropping systems, especially vegetables, ornamentals, berries and culinary herbs. The vertical cropping systems are an attempt to optimize space utilization and to maximize yield. Vertical cropping systems need to solve uneven light distribution because the upper plants get lighter than the lower ones Raviv and Lieth 2008.

Nozzles come in different spray patterns. Three different nozzles were used in this work and the best result was in a full cone nozzle pattern, according to NASA, 2006.

Stephanie, (2016), studied production for Iceberg lettuce and celery in NFT. Productivity of lettuce and celery after 3 weeks was $0.23 \mathrm{~m}$ for lettuce and width of $0.25 \mathrm{~m}$ and celery with height of $0.38 \mathrm{~m}$.

The University of Mississippi compared product yield of crops grown in aeroponic systems and in soil. Researchers found that the yields of plants grown with aeroponic technology were more than $30 \%$ bigger on the average.

According to NASA, plants grow up to 3x faster in aeroponic systems compared to soil (Spinoff, 2006).

Touliators, D. et al. (2016), found $43 \%$ less lettuce crop productivity than top layer in "VFS".

Teegerstrom et al., 2014, found that energy use related to the conventional production of head lettuce in Arizona was limited to the 
direct use of fossil fuels by farms during operations, and to the use of electricity in the pumping of irrigation water. An average estimate of fuel use was derived from the Yuma County crop budgets for head lettuce production developed by the University of Arizona Cooperative Extension. Acker, et al., 2015, found that the average value was then converted to $(\mathrm{kJ} / \mathrm{kg} / \mathrm{y})$ using the estimated average yield for conventional lettuce and assuming one crop of lettuce. It was conservatively assumed that all farms require energy to pump irrigation water and that all of the pumps use electricity. Using an estimate of $1037 \mathrm{~kW} . \mathrm{h}$ per acre, foot pumped.

- The aims of this study were to design a proper system for a vertical farming irrigation system " VFS" for lettuce and celery crops to get the best vegetative growth uniformity along vertical axis of planting pipe (tube), maximum water use efficiency(WUE), minimum energy consumption, and maximum fresh yield per square meter.

\section{2-MATERIALS AND METHODS}

2.1 Experimental layout: Layout and procedure are described in Fig. (1). However, the experimental layout included frame, P.V.C. pipes, irrigation unit that consisted of (pump, nozzle, P.V.C. pipe, $16 \mathrm{~mm}$ P.E tubing), plastic cups, seedlings of lettuce and celery, and perlite with nutrient solution.

The system consists of:

2.1.1 P.V.C. pipes: A P.V.C. pipe of $1.5 \mathrm{~m}$ length and $200 \mathrm{~mm}$ OD with 27 uniformly distributed perforations of $60 \mathrm{~mm}$ OD along the pipe length and the perimeter had ( 3 perforations (group) on the perimeter in 9 layers along the pipe length) was used to put the seedling cups inside the pipe.

2.1.2 Irrigation unit: A centrifugal pump, $1.0 \mathrm{~kW}$, model HP-8000, was placed outside the wooden frame, with flow rate of $3500 \mathrm{lph}$ at $30 \mathrm{~m}$ head. The pump was connected to the irrigation system using P.V.C. main line of $32 \mathrm{~mm}$ OD, and P. E. tubing of $16 \mathrm{~mm}$ OD to transfer water to the nozzle, which was put on the top of the pipe along the pipe axis.

2.1.3 Plant material: Seedlings of lettuce, (Lactuca Sativa, Lollo Rosso, cv. Fortress) and seedlings of celery, (Apium Graveolens) were 
transported on the vertical farming irrigation system 'VFS' of aeroponics in 5Apr. 2016 to 5May 2016, crop harvesting date.

2.1.4 Tank: A cylindrical tank with capacity of about $1.76 \mathrm{~m}^{3}$, of $1.5 \mathrm{~m}$ diameter and $1 \mathrm{~m}$ length was used to supply and recycle nutrient solution for the "VFS".

2.1.5 Frame: A wood frame was constructed with dimensions of $(600 \mathrm{~cm}$ length, $50 \mathrm{~cm}$ depth and a $100 \mathrm{~cm}$ width) and covered with a polyethylene sheet to collect water and nutrient solution for recycling.

2.1.6 Nozzle: Three types of spray nozzle were used with hydraulic specifications shown in the following table (1):

Table (1): Hydraulic specifications for used nozzles

\begin{tabular}{|c|c|c|c|c|}
\hline No & Nozzle & $\begin{array}{c}\text { Head } \\
(\mathbf{m})\end{array}$ & $\begin{array}{c}\text { Discharge } \\
(\mathbf{l p h})\end{array}$ & $\begin{array}{c}\text { Droplet size } \\
(\mu \mathrm{m}-\mathrm{DS})\end{array}$ \\
\hline 1 & Fogger & 30 & 10 & 45 \\
\hline 2 & Mini sprinkler & 20 & 200 & 75 \\
\hline 3 & Micro sprinkler & 20 & 70 & 60 \\
\hline
\end{tabular}
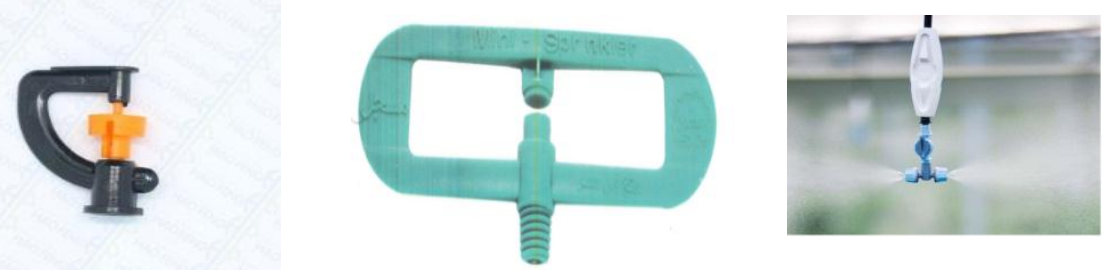

\section{Nozzle types:}

\section{Fig.(1):Micro-sprinkler Mini sprinkler Fogger}

2.1.7 Nutrient solution: Inorganic nutrient solution developed by (ElBehairy, 1994) was used, consisting of: N 259.6, P 35, K 300, Ca 160.2, Mg 50, S 221, Fe 5, Mn 1, B 0.3, Cu 0.1, Mo 0.1, and Zn 0.1 ppm.. The electrical conductivity (EC) of the nutrient solution was maintained between $0.31-0.33$ mmhos $\mathrm{cm}-1$ and the $\mathrm{pH}$ was maintained in a range of about 5.5-6.5 by using phosphoric acid for all-organic solutions. On the other hand, the nutrient solution volume was adjusted once a day by adding tap water up to recognized mark level in the tank. The amount of water was measured and recorded for (CUW). The nutrient solutions were completely refreshed every day.

2.1.8 Lightning time: 9 hours of solar radiation from direct sun. 

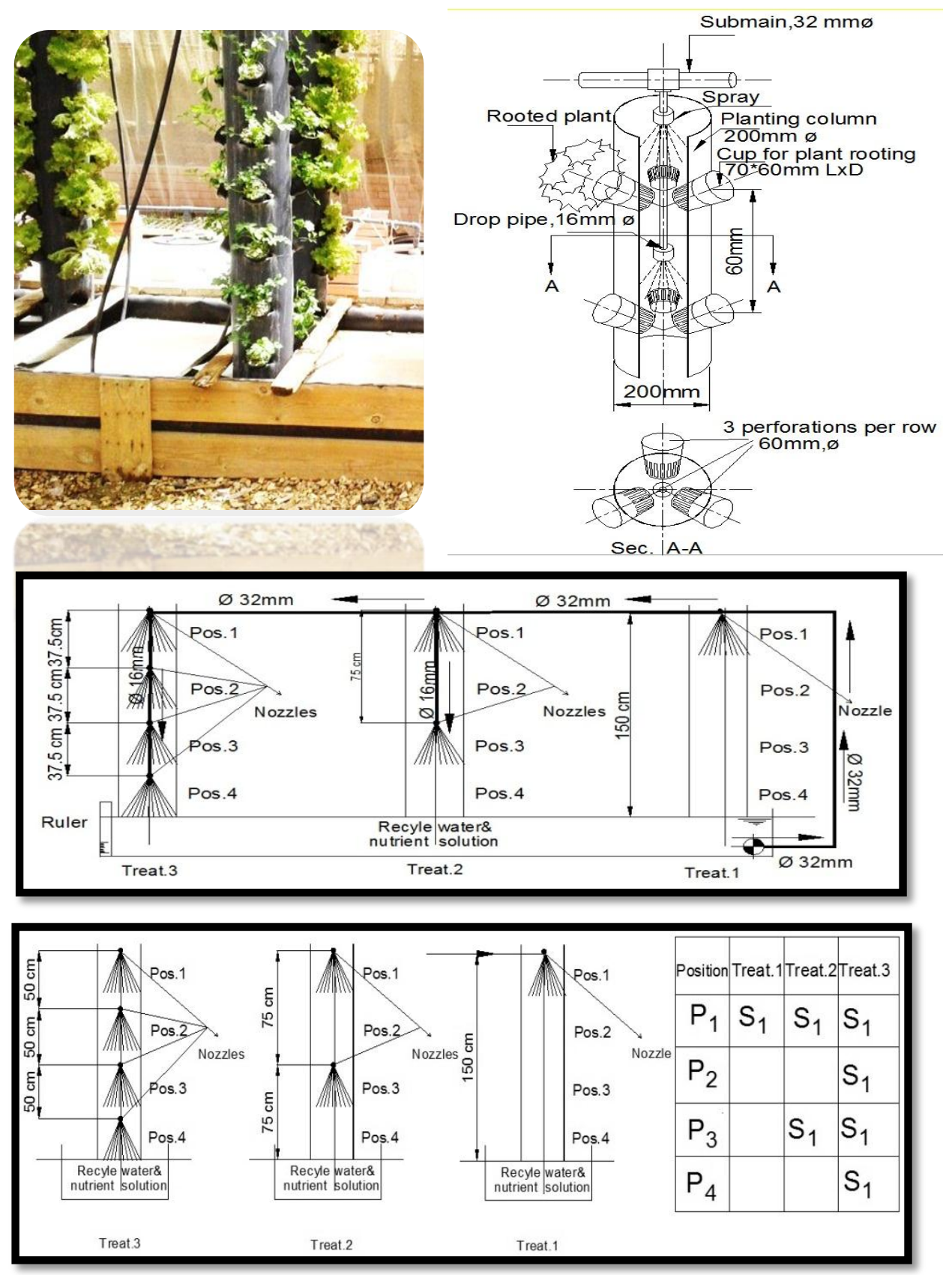

Fig (2): Experimental layout for vertical farming system "VFS".

\subsection{Study factors:}

- Plant factors; Two crops( lettuce, and celery ) were used to test and evaluate the developed 'VFS' 
- Nozzle types: Three types of spray nozzles were tested, according to the hydraulic specifications shown in table.

- Nozzle position on vertical pipe: Four positions were selected along vertical axis of pipe, in Fig.2, to test the effect of nozzle positions and number on the pipe on 'VFS' performance.

- Environmental factors: Temperature and humidity were kept constant and recorded according to test conditions.

- Operating factors: The system was automatically adjusted to operate 3 minutes/hour every day; from 7 am to $7 \mathrm{pm}$ (24min./day); Bakr et al., 2017.

- Hydraulic system: Pump specifications are as shown.

- A regulator valve was used to control the spray-nozzle pressure.

2.3 Determination of WUE for productivity of lettuce and celery.

WUE: according to Jensen (1983) is as follows:

$\mathbf{W U E}=\mathbf{Y} / \mathbf{W}$

Where:

WUE: $\mathrm{kg}$ fresh yield $/ \mathrm{m}^{3}$ water.

Y: Total fresh yield, $\mathrm{kg}$.

W: Total applied irrigation water, $\mathrm{m}^{3}$.

2.4 Plant measurements: Every day, from transplanting, the following measurements of vegetative growth were recorded, including growth indicator parameters. However, the indicated parameters and attributed indices can be categorized as follows:

2.5 Vegetative growth parameters: Plant growth height $(\mathrm{cm})$.

2.6 Yield productivity parameters: Fresh vegetative growth yield $\left(\mathrm{kg} / \mathrm{m}^{2}\right)$.

2.7 Power consumption $(\mathbf{P c})$ : Pc was estimated according to the

following equation:

$$
P c=\frac{q \times h \times w}{\eta},------(2-1)
$$

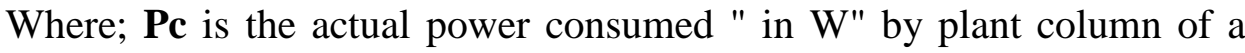
number of plants under spray head " $h$ " in meters and discharge "q" in $\mathrm{m}^{3} / \mathrm{s}$, "w" specific weight in $\mathrm{N} / \mathrm{m}^{3}$, and " $\eta$ " efficiency of pump. 
- Specific plant energy consume (SEC): SEC was estimated according to the following:

$$
S E C=\frac{q \times h \times w \times T}{M \times \boldsymbol{\eta}} \times \boldsymbol{C}-------(2-2)
$$

Where "C" is the conversion from "W.s/kg/y" to "kJ/kg/y", "M" is in "kg" of total yearly fresh yield, and "T" is time in hours for one year.

\section{RESULTS AND DISCUSSION}

\subsection{Effect of nozzle type on vegtative growth along vertical axis} under different nozzle positions:

\section{Lettuce crop}

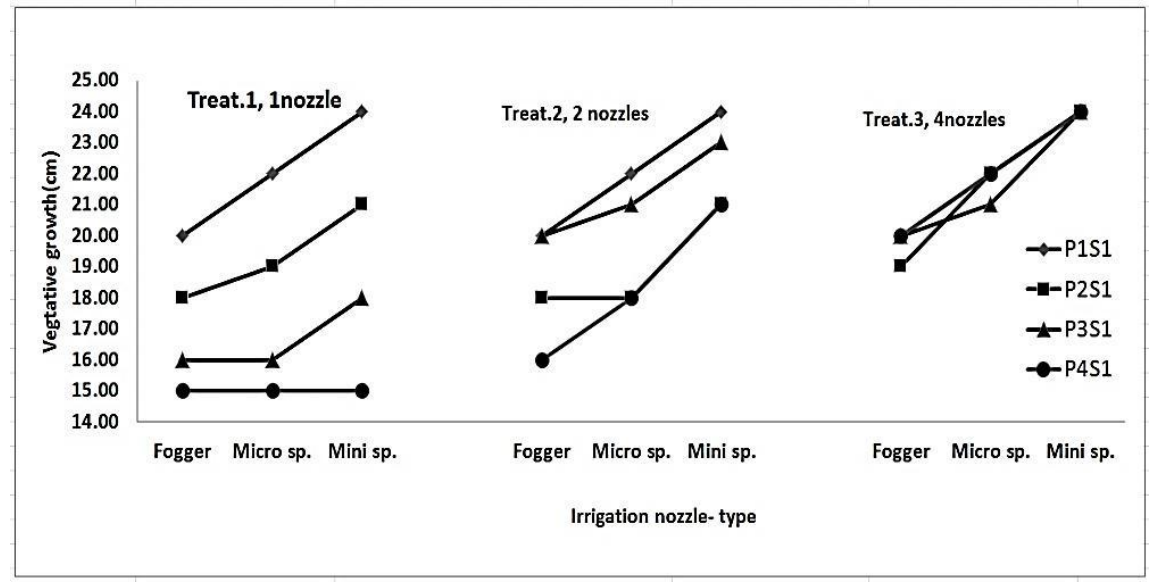

\section{Celery crop}

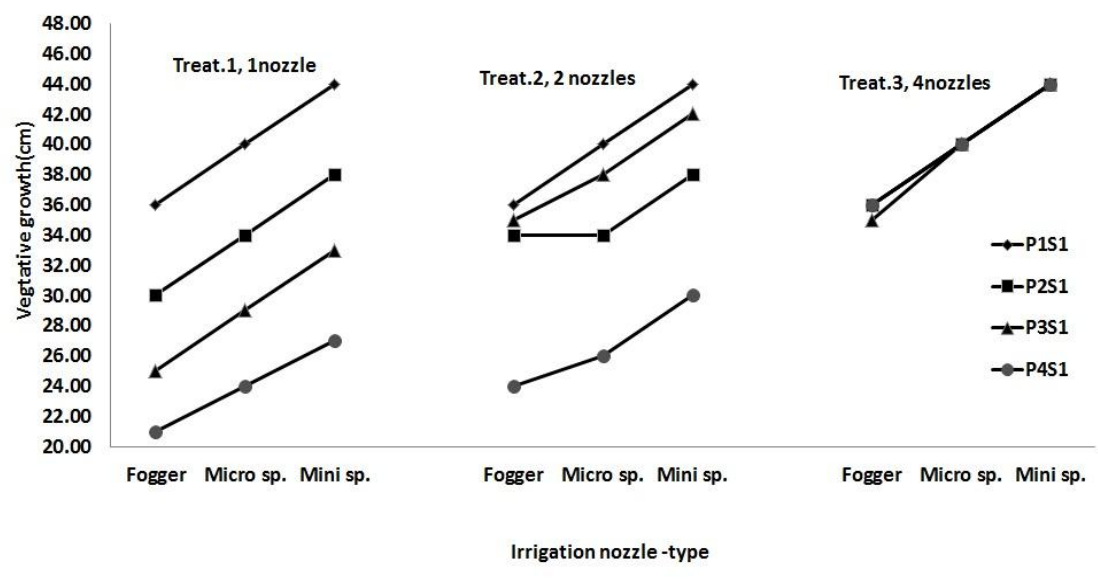

$* \mathbf{P}_{1} \mathbf{S}_{1} ; \mathbf{P}_{2} \mathbf{S}_{1} ; \mathbf{P}_{3} \mathbf{S}_{1} ; \mathbf{P}_{4} \mathbf{S}_{1:}$ Position of plant on (VFT).

Fig.(3.1): Effect of irrigation nozzle type on vegtative growth for lettuce and celery crops. 
Fig.(3.1) shows that the longest vegtative growth of lettuce and celery was recorded by using four nozzles along the vertical tube axis as 24 and $46 \mathrm{~cm}$ at bottom layer of the planted column of farming tube, with increased ratios of 37.5 and $52.3 \%$ compared with using one mini sprinkler nozzle for lettuce and celery crops resp.. Meanwhile, by using two nozzles along vertical tube axis, the vegtative growth of lettuce and celery was $21,30 \mathrm{~cm}$ at bottom layer of the planted column of farming tube, with increased ratios of 28.6 and $10.0 \%$ compared with using one mini sprinkler nozzle for lettuce and celery crops resp... Increase may be due to the uniformity distribuation of the niutrent soluation along vertical tube axis.

It is also clear that a great variation of vegtative growth was noticed by using one nozzle along the vertical farming tube axis with 25, 31.8 and $37.5 \%$ for fogger, micro sprinkler, and mini sprinkler for lettuce crop resp., and 41.7, 40, and $38.6 \%$ for fogger, micro sprinkler, and mini sprinkler for celery crop resp.. Meanwhile, by using four nozzles along the VFT axis, a minimum variation on vegtative growth was noticed along tube axis with $5 \%$ for all tested nozzle types.

A good vegtative growth was recorded along the VFT axis for all treatments by using mini sprinkler nozzle system, compared with other nozzle systems. Vegtative growth on the lower tube position increased from $15 \mathrm{~cm}$ to $24 \mathrm{~cm}$ for one and four nozzle treatments for lettuce crop resp., and increased from $26 \mathrm{~cm}$ to $46 \mathrm{~cm}$ for one and four nozzle treatments for celery crop resp.. That was due to the homogenuity of droplet size distrbuation along the vertical farming tube axis.

\subsection{Effect of nozzle type on WUE at different positions along the vertical farming tube "VFT" axis:}

Fig.(3.2) shows the relation between nozzle type and the WUE under different number of nozzles and positions. It was noticed that mini sprinkler recorded the highest WUE $11.2,8.8,8 \mathrm{~kg} / \mathrm{m}^{3}$ for lettuce crop, and $12.8,12.4,9.75 \mathrm{~kg} / \mathrm{m}^{3}$ for celery crop by using four, two, and one nozzle along the "VFT" axis with an increasing ratios of 21.5, $28.6 \%$ for lettuce crop, and 3,23.8\% for celery crop, compared with micro and fogger nozzles resp.. That may be due to the highest droplet size (75 $\mu \mathrm{m}$ DS) recorded, compared with other tested nozzles. 


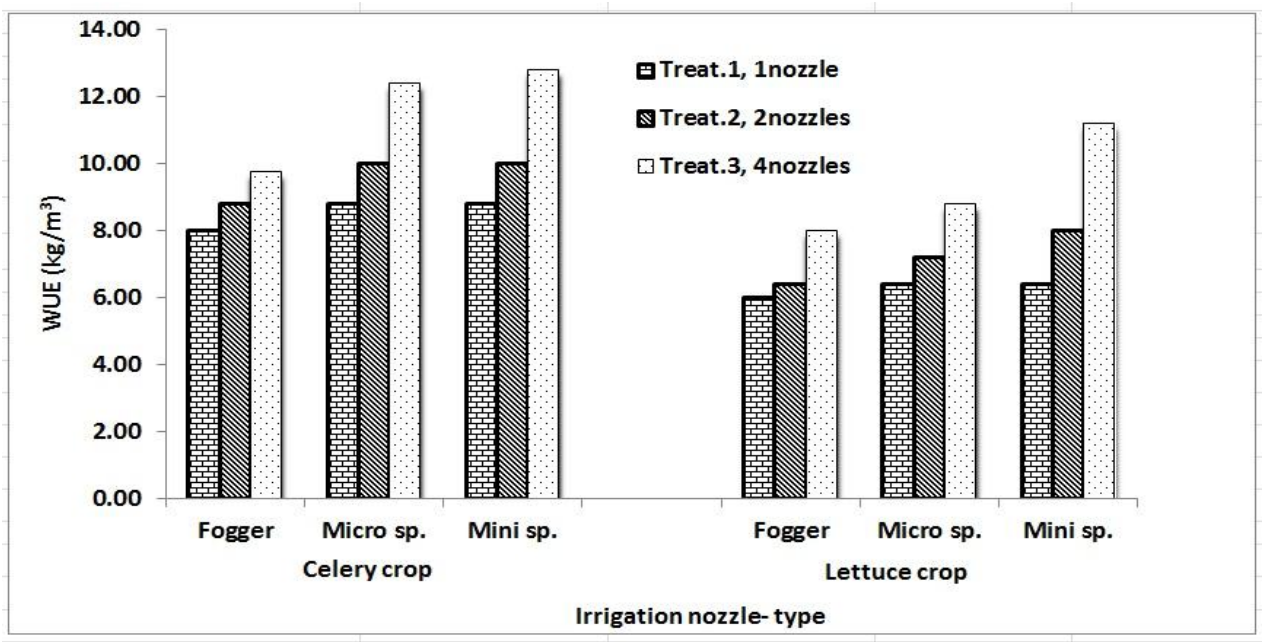

Fig.(3.2) Effect of irrigation nozzle type on WUE for lettuce and celery crops.

3.2 Effect of droplet size, nozzles type and number along the "VFT" on energy requirement $/ \mathrm{kg}$ of lettuce and celery crops.

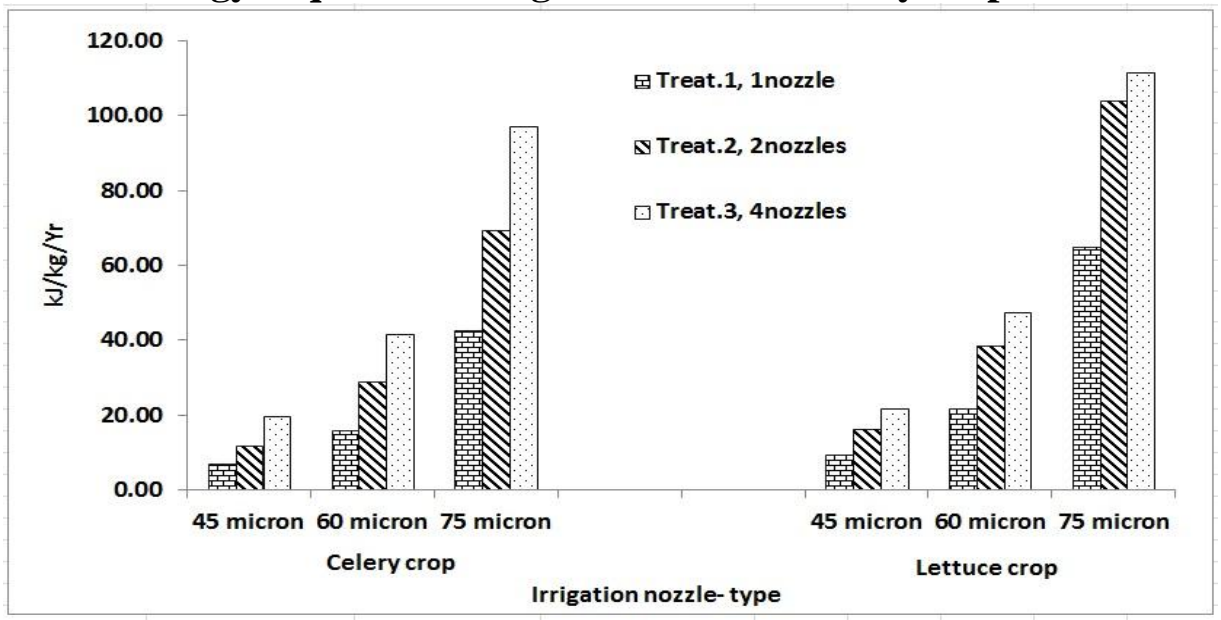

Fig.( 3.3) Effect of droplet size, nozzles type, number on energy requirment for lettuce and celery crops.

The maximum energy requirements of lettuce and celery crops were $111.1,97.2 \mathrm{~kJ} / \mathrm{kg} / \mathrm{y}$ for lettuce and celery crops, by using four nozzles (75 $\mu \mathrm{m}$-DS) along the "VFT" for all tested nozzle types. The minimum 
energy requirements, of lettuce and celery crops were $9.22,6.9 \mathrm{~kJ} / \mathrm{kg} / \mathrm{y}$ by using one nozzle ( $45 \mu \mathrm{m}$-DS) along the "VFT" for all tested nozzle types.

\subsection{Effect of nozzle type on growth uniformity at different positions} along the "VFT" axis:

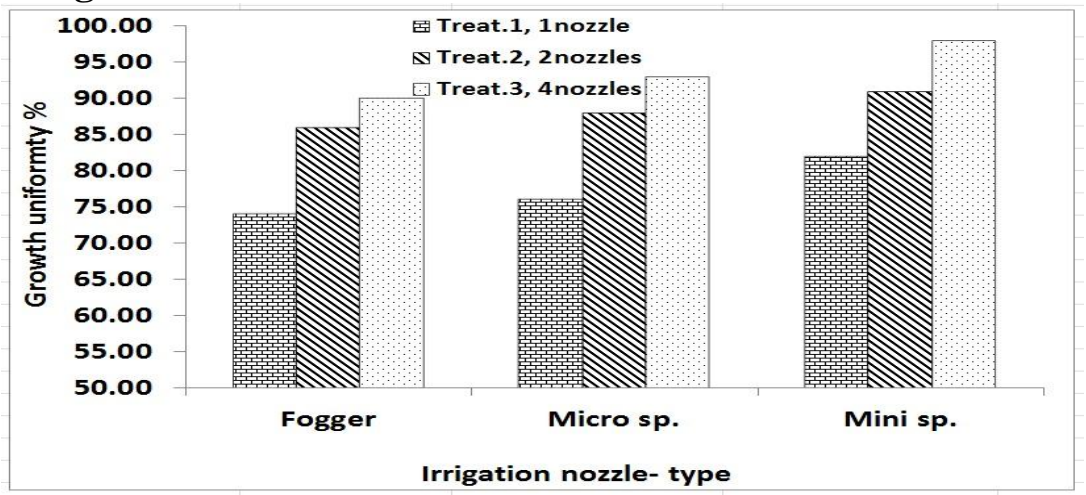

Fig.( 3.4 ) : Effect of nozzle type on growth uniformity for lettuce and celery crops.

The figure shows that the best uniformity of vegetative growth was $96 \%$ by using four mini sprinkler nozzles along the "VFT" axis. The minimum vegetative growth uniformity was $76 \%$ by using one fogger sprinkler nozzle along the "VFT" axis.

\subsection{Effect of nozzle type on fresh weight for lettuce and celery crops}

under different nozzle positions and number.

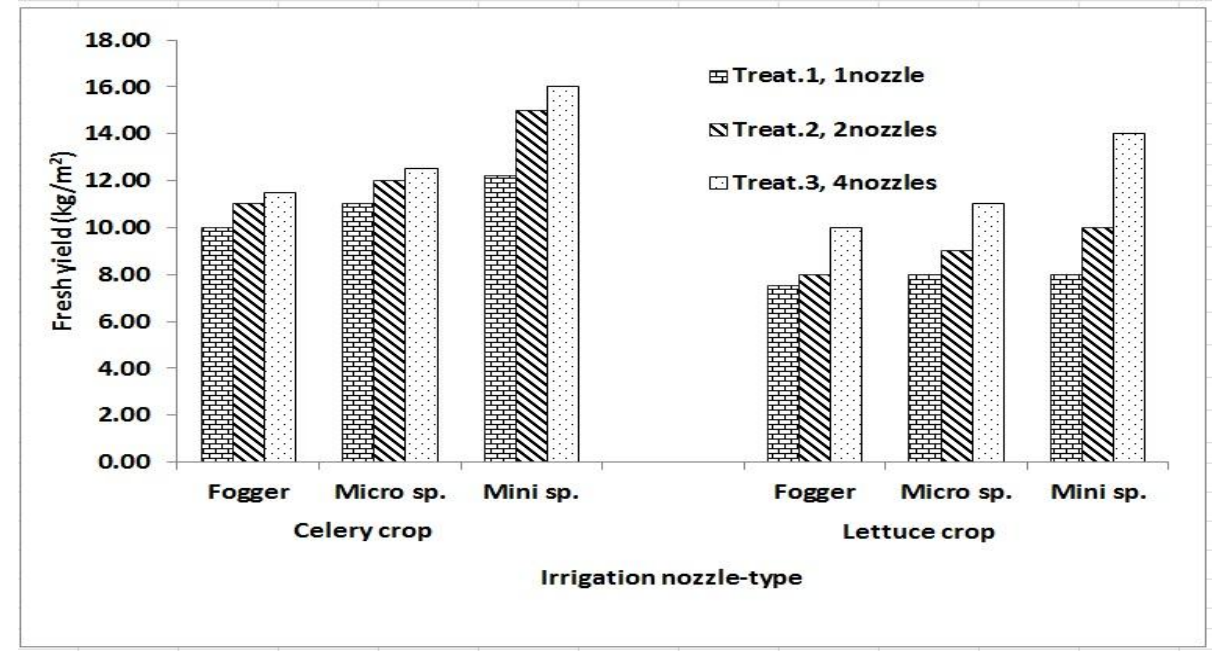

Fig.(3.5 ): Effect of nozzle type on fresh yield for lettuce and celery crops. 
Fig. (3.5) represents the effect of nozzle type on fresh yield for lettuce and celery crops under different nozzle positions and number. It is clear that by using four nozzles /"VFT", the maximum productivities of lettuce and celery fresh yield were $14,11,10 \mathrm{~kg} / \mathrm{m}^{2}$ for lettuce crop, and $16,12.5$, $11.5 \mathrm{~kg} / \mathrm{m}^{2}$ for celery crop, for mini sprinkler, micro sprinkler and fogger nozzles resp., whereas by using one nozzle/"VFT", the minimum productivities of lettuce and celery fresh yield were $8,8,7.5 \mathrm{~kg} / \mathrm{m}^{2}$ for lettuce crop, and $12.2,11,10 \mathrm{~kg} / \mathrm{m}^{2}$ for celery crop, for mini sprinkler, micro sprinkler and fogger nozzles, resp..

\subsection{Effect of nozzle type on consumptive energy:}

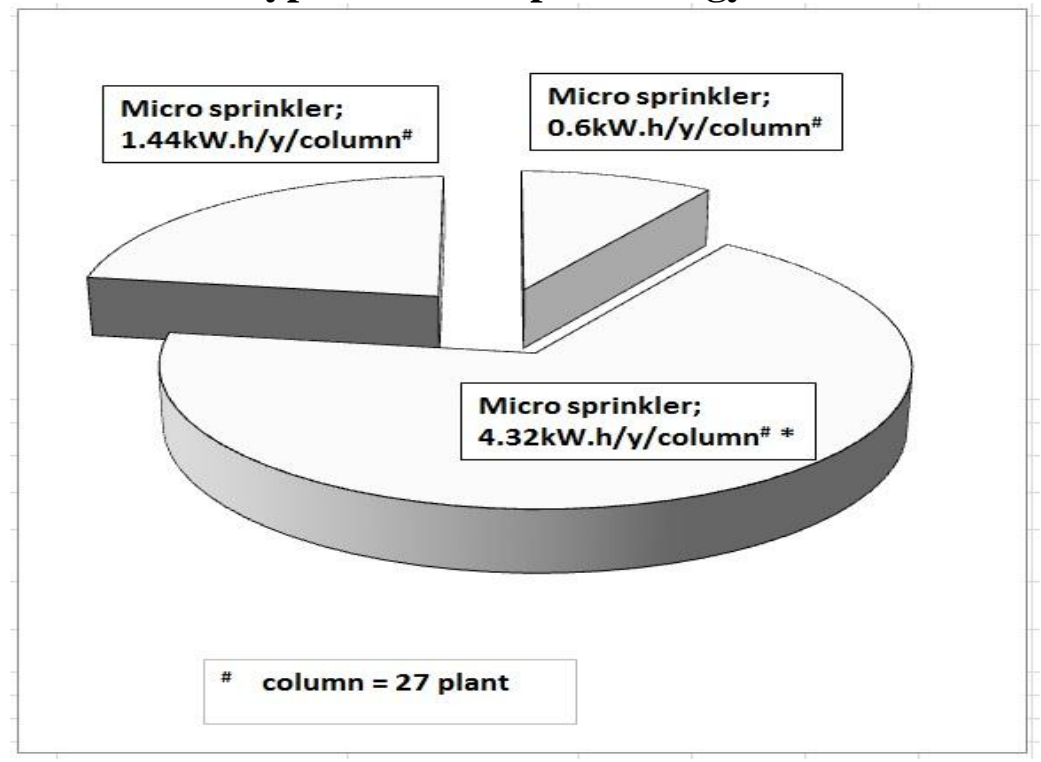

Fig.(3.6): Effect of nozzle type on consumptive energy.

** Based on yearly operation for one column with 27 plants, under spray pressure of $30 \mathrm{~m}$ head and total discharge of $40 \mathrm{l} / \mathrm{h}$. Other figures were similarly obtained for the different nozzle types (Eq.2-2) in the section of "Materials and Methods".

Fig. (3.6) shows the average yearly consumptive energy used for operating different nozzle types on vertical farming tube (four nozzle/"VFT"). 
It is clear that the maximum yearly use of energy was $4.32 \mathrm{~kW} . \mathrm{h} / \mathrm{y}$, when using mini sprinkler nozzle, that increased by $81 \%$ compared with fogger nozzle, due to increasing system discharge.

Meanwhile, the minimum yearly use of energy was $0.6 \mathrm{~kW} . \mathrm{h} / \mathrm{y}$, when using fogger sprinkler nozzle.

\subsection{Effect of droplet size and nozzle type on operating and production} criteria when using four nozzles/"VFT" for lettuce and celery crops:

\begin{tabular}{|c|c|c|c|c|c|c|}
\hline System & Dropletsize $(\mu=\mathrm{m})$ & |) Fresh yield||kgly & Consumptive energy/kW.hly & y) Total $\cos t(\mid$, E.E|y) & 1) Crop price (LE.E) & y) Profit(LEEly) \\
\hline Fogger & 45.00 & 100.00 & 0.60 & 200.00 & 800.00 & 600.00 \\
\hline Micro_sprinkler & 60.00 & 110.00 & 1.44 & 71.00 & 880.00 & 809.00 \\
\hline Mini_sprinkler & 75.00 & 140,00 & 4.32 & 73.00 & 1120.00 & 1047,00 \\
\hline
\end{tabular}

\begin{tabular}{|c|c|c|c|c|c|c|}
\hline System & Dropletsize( $\mid \mu \mathrm{m})$ & 1) Fresh yield||(kg|y) & Consumptive energy/|kW.hly & |Total cost $(\mid$ LEE $|y|$ & Crop price (LEVI) & | ProfittLLE|l|y| \\
\hline Fogger & 45,00 & 110,00 & 0.600 & 200.00 & 1100,00 & 900.00 \\
\hline Micro_sprinkler & 60.00 & 125.00 & 1.440 & 71.00 & 1250,00 & 1179.00 \\
\hline Mini_sprinkler & 75,00 & 160.00 & 4.320 & 73.00 & 1600,00 & 1527,00 \\
\hline
\end{tabular}

Table (2): Nozzle droplet size and type, yearly production in " $\mathrm{kg} / \mathrm{m}^{2} / \mathrm{y}^{\prime}$, use of energy in "kW.h/y", initial nozzle cost, total production price, and net profit.

It is clear that, by increasing droplet size of nozzle, the net profit, the productivity and consumptive energy increased when using four nozzles, each "VFT".

The maximum net profit was 1047, 1527LE/y/column* for lettuce and celery crops, when using mini sprinkler $(75 \mu \mathrm{m}$-DS) $* *$ with an increase of $42.7,41.1 \%$ for lettuce and celery crops, compared with using fogger nozzle $(45 \mu \mathrm{m}-\mathrm{DS})$.

- $*$ Column $=27$ plant

- **um-DS : nominal droplet size in Micro- meter. 


\section{CONCLUSION}

- The highest vegtative growth of lettuce and celery, recorded by using four nozzles along the vertical tube axis, was 24 and $46 \mathrm{~cm}$ at bottom layer of the planted column of farming tube.

- The highest values of WUE, under different number of nozzles and positions, was $11.2,8.8,8 \mathrm{~kg} / \mathrm{m}^{3}$ for lettuce crop, and 12.8, 12.4, 9.75 $\mathrm{kg} / \mathrm{m}^{3}$ for celery crop by using four, two, and one nozzle along the "VFT" axis .

- The maximum energy requirements of lettuce and celery crops were $111.1,97.2 \mathrm{~kJ} / \mathrm{kg} / \mathrm{y}$ for lettuce and celery crops, by using four nozzles (75 $\mu \mathrm{m}-\mathrm{DS}$ ) along the "VFT", for all tested nozzle types.

- The maximum productivity of lettuce and celery fresh yields were recorded as $14,11,10 \mathrm{~kg} / \mathrm{m}^{2}$ for lettuce crop, and $16,12.5,11.5 \mathrm{~kg} / \mathrm{m}^{2}$ for celery crop, for mini sprinkler, micro sprinkler and fogger nozzles resp.,

- The maximum consumptive use of energy was $4.32 \mathrm{~kW} . \mathrm{h} / \mathrm{y}$, when using mini sprinkler nozzle, increased by $81 \%$ compared with fogger nozzle.

- The maximum net profit was 1047, 1527LE/y/column, for lettuce and celery crops, by using mini sprinkler (75 $\mu \mathrm{m}-\mathrm{DS})$ compared with using fogger nozzle (45 $\mu \mathrm{m}$-DS).

\section{REFERENCES}

Acker, T.; C. Atwater; W. French; M.Glauth; and Smith D., 2015, Energy and water use in Arizona agriculture, Working paper 08-08.

Bakr, A. S.; Hegazy, M.A.M.; Bedir O.M.A.; El-Morsy, A.T. 2017, The effect of some engineering factors of irrigation system by aeroponics, the $13^{\text {th }}$. Conf. of Agric. Dev. Res.: 115- 131. 
Corvalan, C., S. Hales, and A. J. McMichael. 2005. Ecosystems and human well-being: health synthesis WHO, 240-255.

Eigenbrod, C., and N. Gruda. 2014. Urban vegetable for food security in cities. A review. Agron. Sustain. Dev. 35:483-498.

El-Behairy, U. A., 1994, The effect of levels of Phosphorus and Zinc in the nutrient solution on macro and micro nutrient uptake and translocation in cucumber (Cucumis sativus L.) grown by the Nutrient Film Technique. Ph. D. Univ., London, Wye College England.

Foley, J. A., N. Ramankutty, K. A. Brauman, E. S. Cassidy, J. S. Gerber, M. Johnston, et al. 2011. Soluations for a cultived planet. Nature 478: 337-342.

Jensen, M.E., 1983, Design and operation of farm irrigation systems. Amer.Soc. Agric. Eng. Mich. USA: 827.

Lambin, E. F., H. K. Gibbs, L. Ferreira, R. Grau, P. Mayaux, P. Meyfroidt, Et al. 2013. Estimating the worlds potentially available cropland using a bottom-up approach. Glob. Environ. Change 23: 892-901.

NASA Spinoff (2006). Progressive plant growing has business blooming, Environmental and Agricultural Resources: 68-72.

NASAA Aeroponic

Plants(http://www.nasa.gov/vision/earth/technologies/aeroponic_pla nts.html)

Pandy, B., and K. C. Seto. 2015. Urbanization and agricultural land loss in india: comparing satellite estimates with census data. J. Environ. Manage. 148:- 53-66, Land Cover/Land Use Change (LC/LUC) and Environmental Impacts in South Asia.

Teegerstrom, T.; Palumbo, J.; Zerkoune, M. 2014 Arizona vegetable crop budgets, Western Arizona, Yuma County, La Paz County; 
Coop.Ext., Coll.of Agric. and Life Sc., U. Arizona, Tucson, Arizona, (AZ1263): 230-245.

Tilman, D., C. Balzer, J. Hill, and B. L. Befort. 2011.Global food demand and the sustainable intensification of agriculture. Proc. Natl Acad. Sci., USA 108:20260-20264.

Touliators,T., I.C. Dodd, and M. McAinsh, 2016. Vertical farming increases lettuce yield per unit area compared to conventional horizontal hydroponics, Food and Energy Security, (5)3: 184-191.

Raviv M. and Lieth J.H. (2008). Soilless culture; Theory and practice. London: Elsevier. ISBN: 978-0-444-52975-6.

Savvas D. and Passam H (2002), Hydroponic production of vegetables and ornamentals.

Schwab G.O., Frevert R.K. Edminster T.W. and Barnes K.K. 1981. Soil and water conservation engineering. 3rd Ed. John Wiley, N. Y.: 33-34.

Sonneveld C, Straver N. 1994 Voedingsopplossningen voor groenten en bloemen geteeld in water of substrate. Proefstation voor tuinbouw onder glas te Naaldwijk. Voedingsoplossingen glastuinbouw. No. 8. 10th Ed.: 526-555.

The author acknwoldges, the assistance of M.S.Emam and the staff of the (Central lab. Of Ag. Climate, Dokki, Giza, Egypt) for their help in supporting this study.

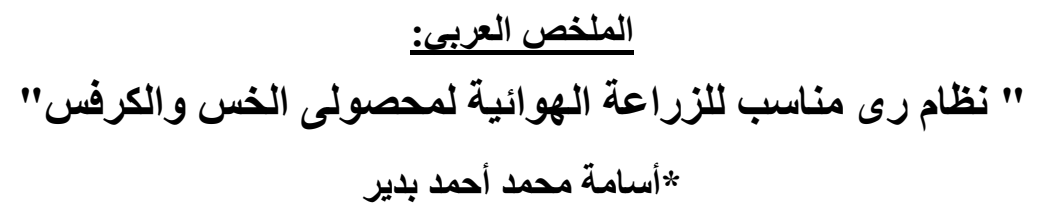

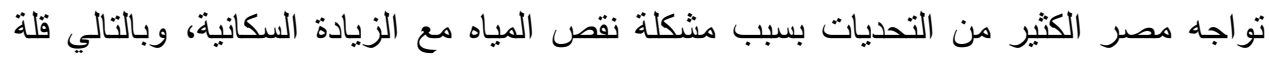

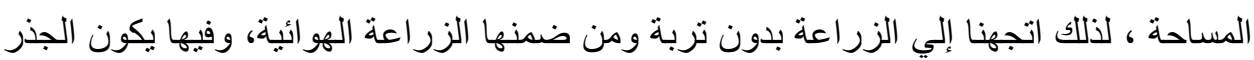

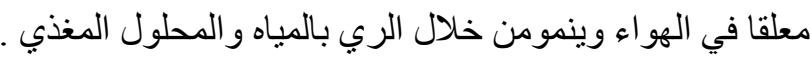
*مدرس الهندسة الزراعية، زراعة عين شمس، القاهرة- مصر. 
ونفذت التجربة الحالية في المعمل المركزي للمناخ الزراعي، مركز البحوث الزراعية، الدقي،

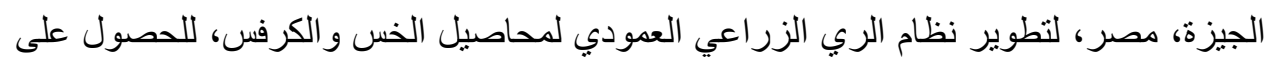

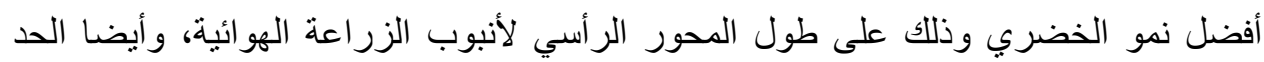

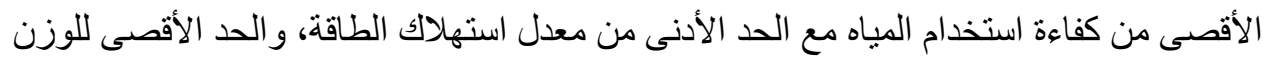
الطازج لوحدة المنر المربع الواحد.

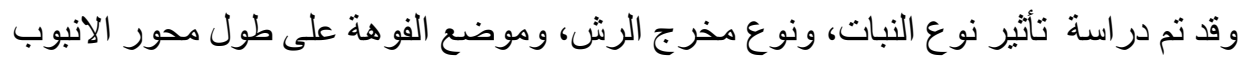

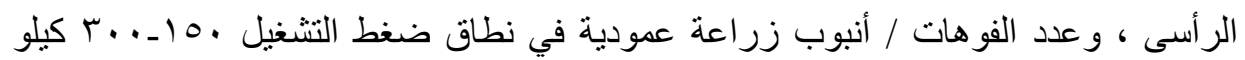

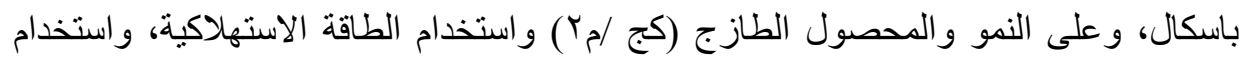

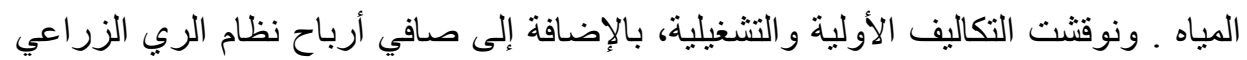

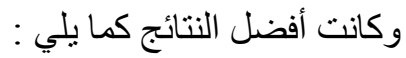

• أعلى نمو نباتي للخضار نتج باستخدام أربع فوهات على طول محور الأنبوب الرأسي.

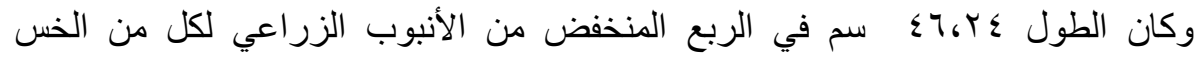

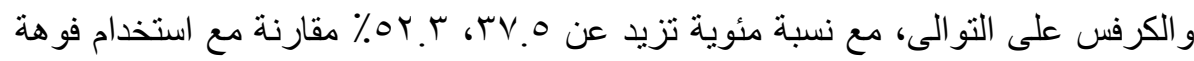

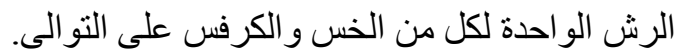

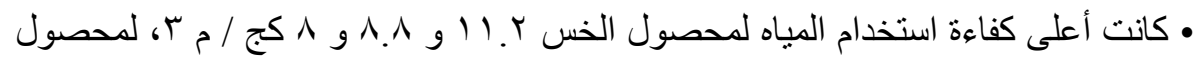

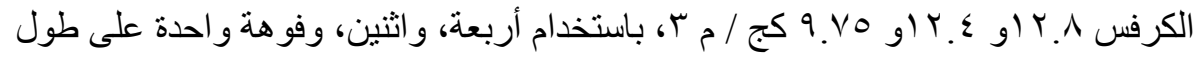

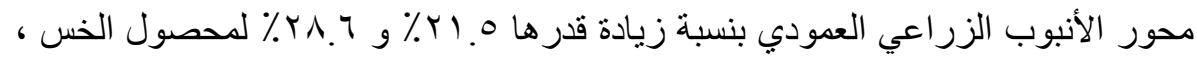

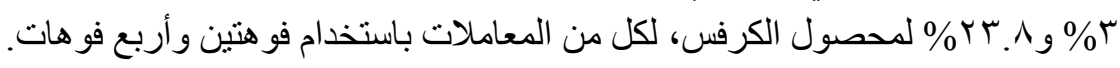

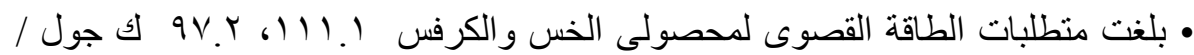

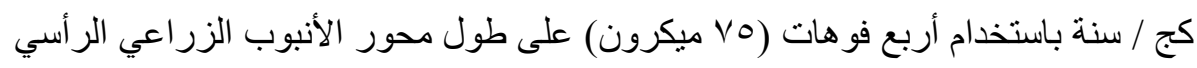
لجميع أنواع الفو هات المختبرة.

• كانت أفضل نسبة للنمو الخضري 9 ٪\% باستخدام أربع فوهات بالمقارنة باستخدام أنظمة

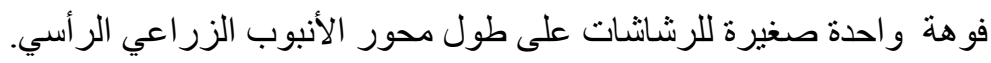

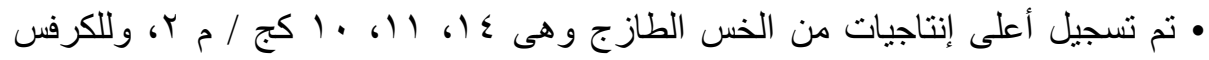

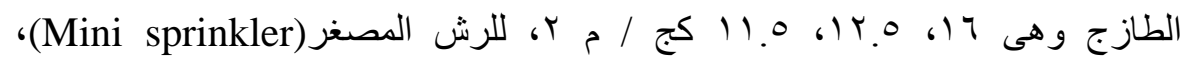

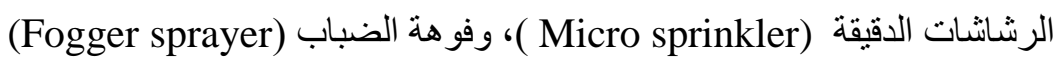




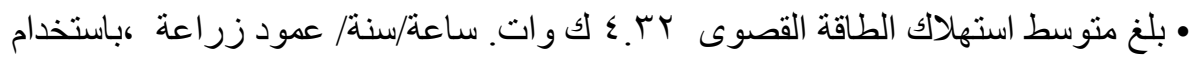

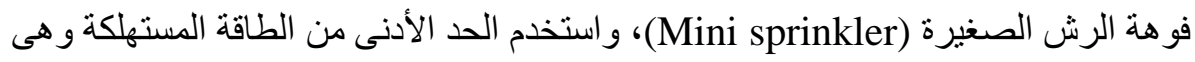
T. .(Fogger

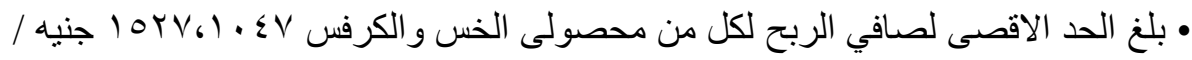

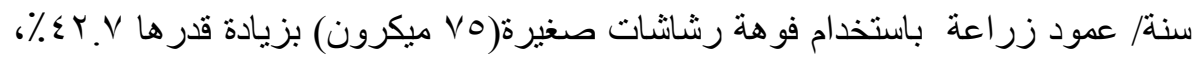

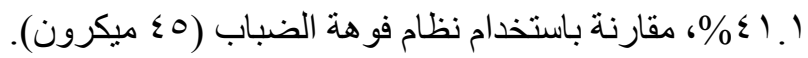

